(8)

\title{
尿 Vakat沃度酸值係數について
}

群馬大學醫學部醫化學教室（指導 山添 钽 授）

米津 穆

西風(1)が疲勞の一測定法こして提唱した尿 Vakat沃度酸植係數は單に筋肉運動に伴子疲勞

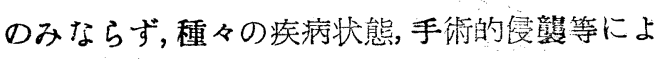
つてる變化を示すといわれ, 疲勞制定法その他 の目的における今後の應用か;期特されるが，そ れが變動を示す生化學的理由ば未に゙明らかでな w.

尿Vakat沃度酸值係數(以下VIQと略す) とは 尿Vakat酸素(以下VO二路す) 尼尿沃度酸值(以

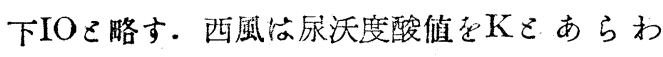
し, Vakat沃度酸值係數をO/Kをあらわしたか，

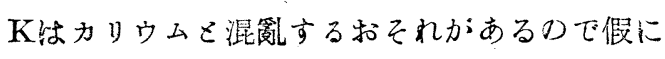
上記のようにあらわした）で除した商であるか ら同じくVIQの增加あるいは減少といつても V O及びIO變動の方向は一樣でない，元來二つ の變動する困子の比率を求めることは便宜上の 問題であることが多く，生体それ自身の變化と しては比率よりもむしろ各因子の增減に意味が あると考へられる.よつて私はVIQの變動をV O及びIOつ兩因子の變動との關連において觀察 しそその意義を明らかにするため本實驗支試み た。

これまで行つた比較的短時間の實驗の範圍內 では種くの條件に伴うIOおよびVIQの變動に は法則性を見出すことが困難であり，從つてV IQの增大に一元的意未認めることが出來な かつたが，一應これまでの賽験成樍を報告して
参考に供したん。

留驗、方法

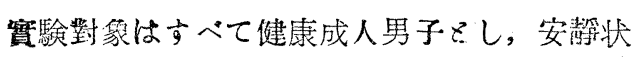
態, 水分攝取, 運動, アドレナリン注射, エフ エドリン注射, 寒冷曝露等の條件の下で多くは 30〜60分の間隔で棌尿老行い, そのVO, 10 そ の他を湘定した。なぶ部の賽験ではVaれa $\mathrm{O}$

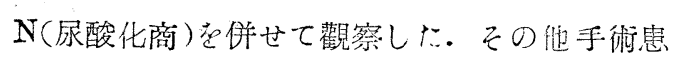
者については逐日的に同樈の测定行行つた。V V Oつ測定仿 chrom酸酸化法(齊藤(3)), IOJ測定 は西風(1)の法に從ひ，その他ドナチオ反應（山 添法(4)，尿全N(Parnas法), 尿 $\mathrm{pH}$ (山添法 5)), 赤松神明反應清水氏變法 $(6)$, 血壓(タイコス)等 を適宜測定した。

\section{賽 驗 成 繢}

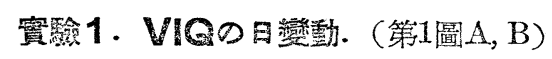

平常の生活條件（特别の勞働起行わず大侑椅

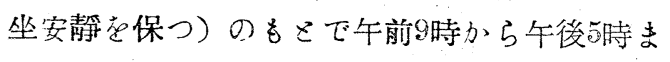
でにわたつて實驗したここの實験では普通の通 り食事提取を行つた。同一被檢者についての2例 の成績夲すと第1圖A及びBの如くである。 第1圆AではＶO及びIOはぼ本行して徐々 に增加定示L, VIQは土大体で正常値20前後の值 を保つ(24.0-14.4). 8時半から10時去での尿 量と全Nは平行して減少するがこっではVO, IOHこれと平行しない.10時以後の經過はVO, IO, 尿量, 全Nの四者はほぼ本行して徐々に 
增加を示してるろ.

第 1 因(A) VIQの日變動

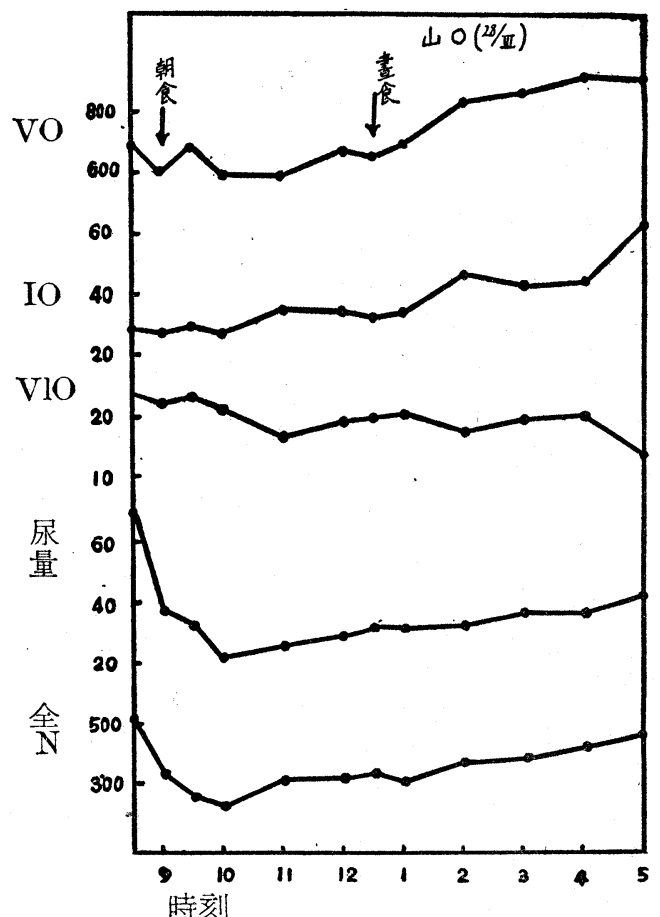

(註)VOはVakat-酸素,IOは沃度酸值，VIQは

Vakat-沃度酸值係數示示す. VO, IO, 尿量, 全N等はすべて1時間值を示す. 以下同し 第1圖BではVOは尿量と一致して著明な變動 を示すが，IOつ變化结尿量上闒係なくほぼ一 定の値を示す。從つてVIQはVOの變化に支配 され，尿量と平行して18.6〜37.7の變化を示し てるる。

VOか;尿全N上正相閣を示すことはすでて齊 藤(7)の指摘するところであり，また短時盟內の 尿全Nの變動は多くの場合尿量区本行する.一 方IOは以トの貿験成續によればVOあるいは尿 量とは一定の關係を示さず, 尿量に件つて增加 する場合と增加しない場合がある。严の結果と して安静状態にお忖るVIQ注尿量（從つてVO） の變化に一致して著しく變化する場合と尿量の
變化に影響されすほぼ一定の值を保つ場合とが 見られた。

第 1 図。(B) VIQの日變動

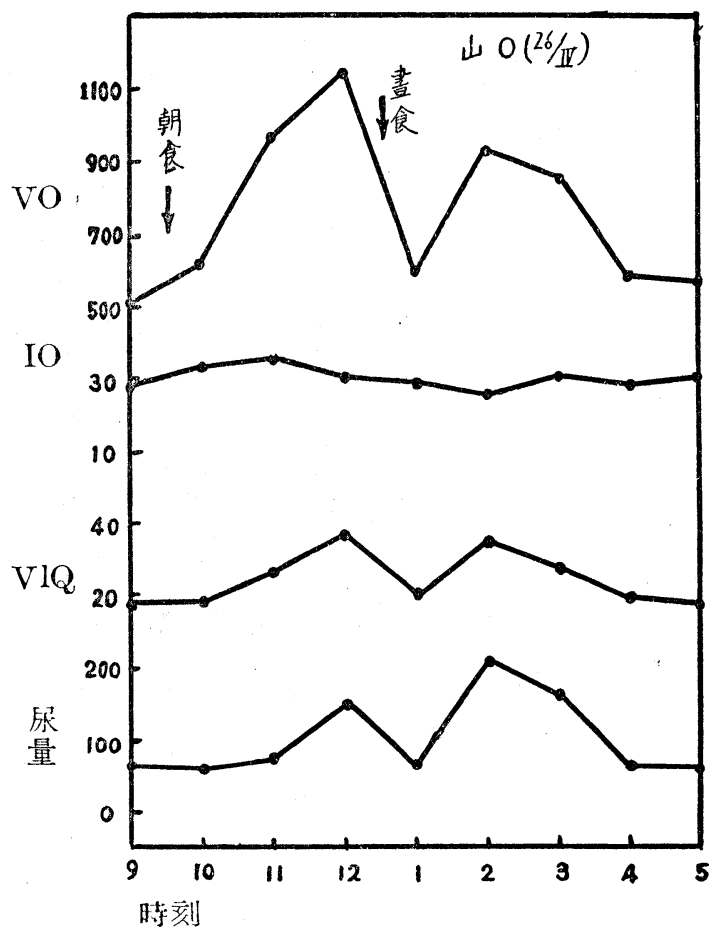

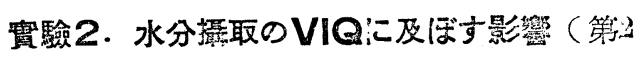
圖)

尿量とIOつ關係在更に詳しく檢討するため に更に他の被檢者について水分攝取の影響につ

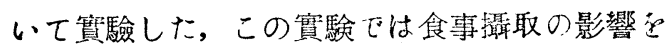
さ付るため朝食は取らなかつた。

第2圖Aの例においては水300cc领用後尿量の 急激な增加に伴ひVOの著しい増加が起つた。 然しIO江一旦やや急激に㴰加した後尿量が更 に增加するにもかかわらす再び低下し，M字型

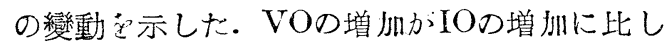
て强いためにVIQ致ほぼVO變動に一致した 山苯示す（11.4から22,3に上昇）。

第2圖Bの例におんてはVO注やはり尿量をほ 
第』図 水分攝取のVIQK及ぼす影響

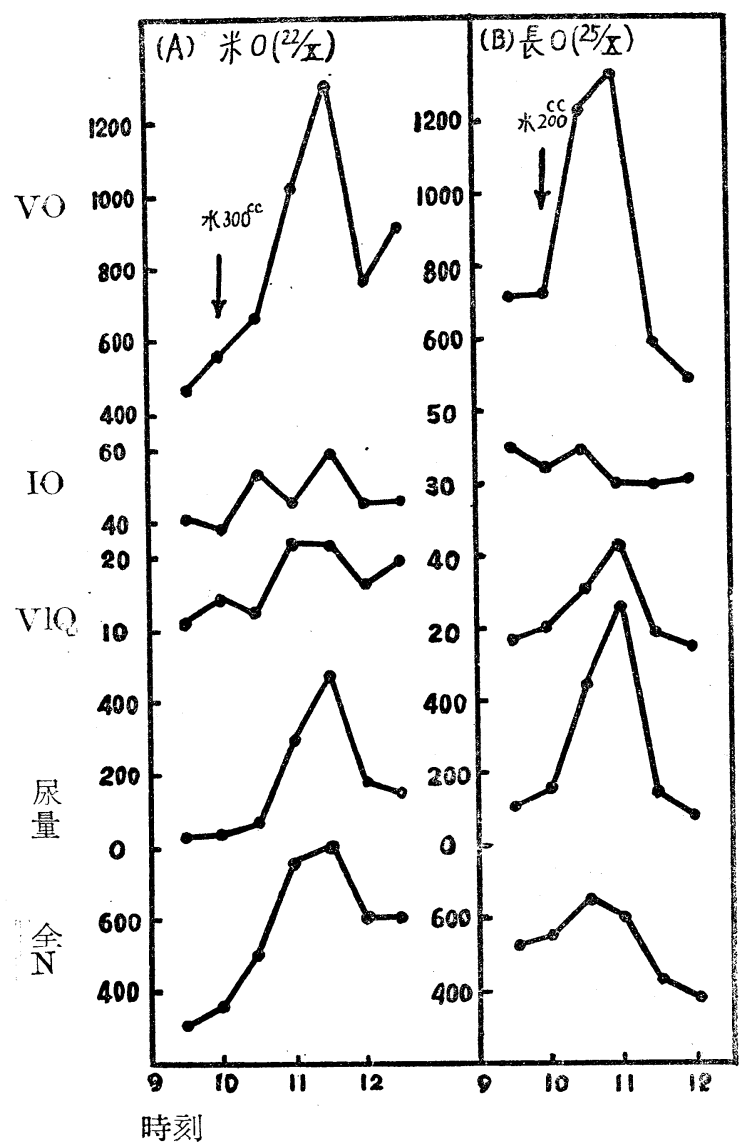

ぼ本行するが, IOは一旦僅かに上昇した後次第 て低下し，VIQ㹥Aの列こ同じくVO（和よび 尿量)の變化にほぼ一政した山在示吉(17.6から 44.2.2亿上昇).

以上の成績によれば水分攝取によるVIQの變 化は主としてVOの變化に支配され，大体尿量 の増加こ一致した山を示し,IOの變化はこれ に比して輕度であり且つ一定の傾向走示さない もののようである。

實驗3．短時間の運動のVIQに及ぼす影響 (第了圖)

同一被檢者について行つた3回の實驗成績邑
第3圖に示す。

第 3 図運動のVIQに及ぼす影響

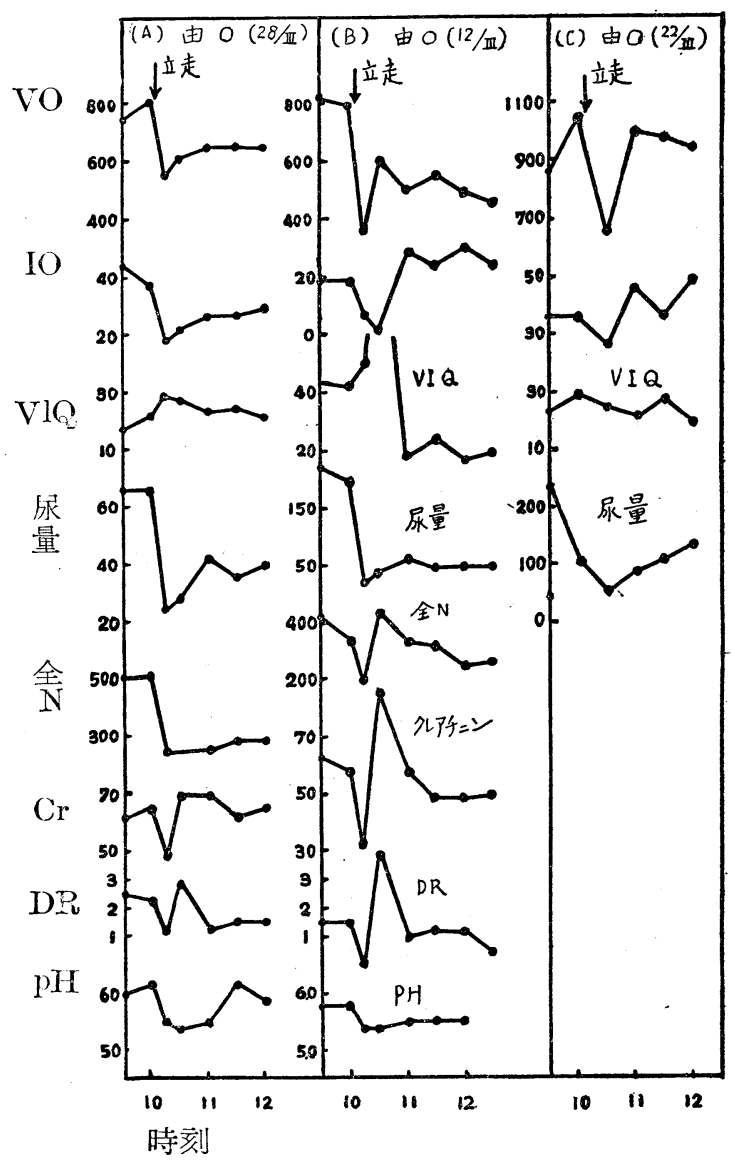

(註) $\mathrm{DR} ：$ ドナヂオ反應山添法

$\mathrm{Cr}$ : : クレアチニン (以下同じ)

AおよびBの例は食事攝取の影響をさ讨るた めに朝食は取らず, Cの例では朝食 (普通食)を 攝取した。運動は10分間の立走(每分約70複步) とした。これはかなり疲労性の運動である。運 動により层量の急激な減少が起りこれに件つ てVO扣よびIOはー・旦減少するが，次で兩者は 徐々になるいは急激に恢復しその恢復の程度は 一樣でない，Aの例ではIOの低下率かＶOそれ より强いためにVIQは全体として上昇の傾向 
にあり，運動前の16.3から運動後15分で29.に に 上昇した、BではVIQに運動前の4.1.9から運動 後一且急激に上昇したが1時間後には低下し最 低16.4を示した。Cでは運動後VIQけ運動前の

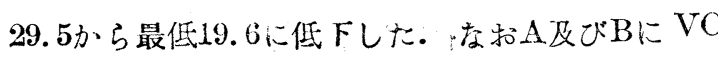
おいてクレアチニン，ドナヂオ反應， $\lfloor\mathrm{pH}$ 等を 測定した，クレアチニンとドナヂオ反應はほぼ 平行して變動したが，尿量とはやや異つた型を 示してるる。但しクレアチニンとドナヂオ反隹 は常に本行するとは限らない, $\mathrm{pH}$ は運動 後低 VlC 下し，次で徐々に恢復を示す。この變化はVO, IOの變化こ一致する樣にも見えるか;他の實験 の成績によれば兩者の間に一定の關係は認めら れない。

以上の實験成績によれば短時間の運動に件い 尿量の減少に一致してVO及びIOは著明な低下 老示すか兩者の低下の相對的絬係によつて VI Qの變化行かならずしも一定せず，上昇する場 合と低下する場合とが認められる。

贯驗4.アドレナリン注射のVIQに及ぽす 影響(第本圖)

山添，由上，關本(8)はアドレナリン注射によ り血壓七昇期にほば一致してしばしばドナヂオ 反應の上䒜が起ることを示した。アトレナリン の作用は一般に運動の影響と類似性があると考 へられるので私はVO及びIOて對するアドレナ リンの注射つ影響を檢討した。

3名つ被檢者（朝食攝取せす）に1000倍塩酸工 ピレナミン(三共)を夫々 $0.3 ， 0.5 ， 0,7 \mathrm{ec}$ を注 射した:なおこの實驗では血壓の變化を合せて 測定した. 3 例とも注射後血壓上昇期に尿量の 一過性つ増加があり，A及びBに和いては VO はほぼこれと一致した山を示したが，IOの變
第 4 図 AdrenalimのVIQに及汪す影響

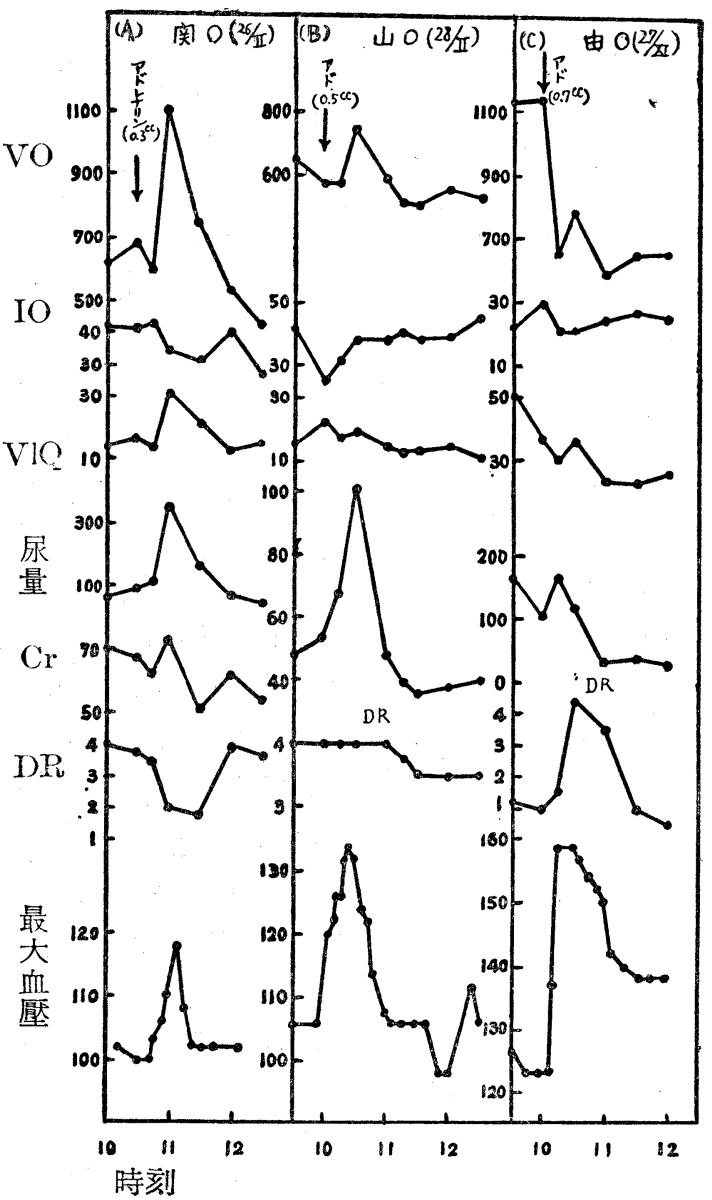

化はほとんど尿量と關係なく，VIQはAでは原 量とほぼ一致した上昇(注射前14.8，注射後最 高32.0)宗し，Bで注㴬後漸次低下した(注 射前23.1，注射後最低11.7). ( ではアアドレナ リン注射後原量がやや増加したにもかかわらす。 VOおよびIO刀低下が起り，VIQはVOこほぼ 平行して變動した。

以トの實驗によればアドレナリン注射の VI QおよびIにおよぼす影響け短時間の運動の場 合と同様に一定の傾向を示さない，但しこの實 験で台被檢者およびアドレナリン注射量が異る 
から一定しないのはそのためかも知れない。な おドナヂオ反隹もこの賽験では一定の成績を示 さない、Aにおいてドナヂオ反應つ低下した理 由は不明である。尿量の著しい增加にこもなつ てドナヂオ反應值かしじしば減少する現象につ レては别に研究中である。

賔驗5.ニフェドリン注㫄のVIQに及度す影

\section{饗(第》圖)}

エフェドリンの腎㙨能におよ汸す影響交らび にそれとアドレナリン作用との異同については 議論があるが(9)，その䦗題は暫く置き，VO. IO，VIQその他に對するエフェドリンの影響を 検行した。この實験でも食事攝取の影響をさけ るために朝食㣖攝取しなかつつた。

第 5 図 EphedrineつVIQに及ぼす影響

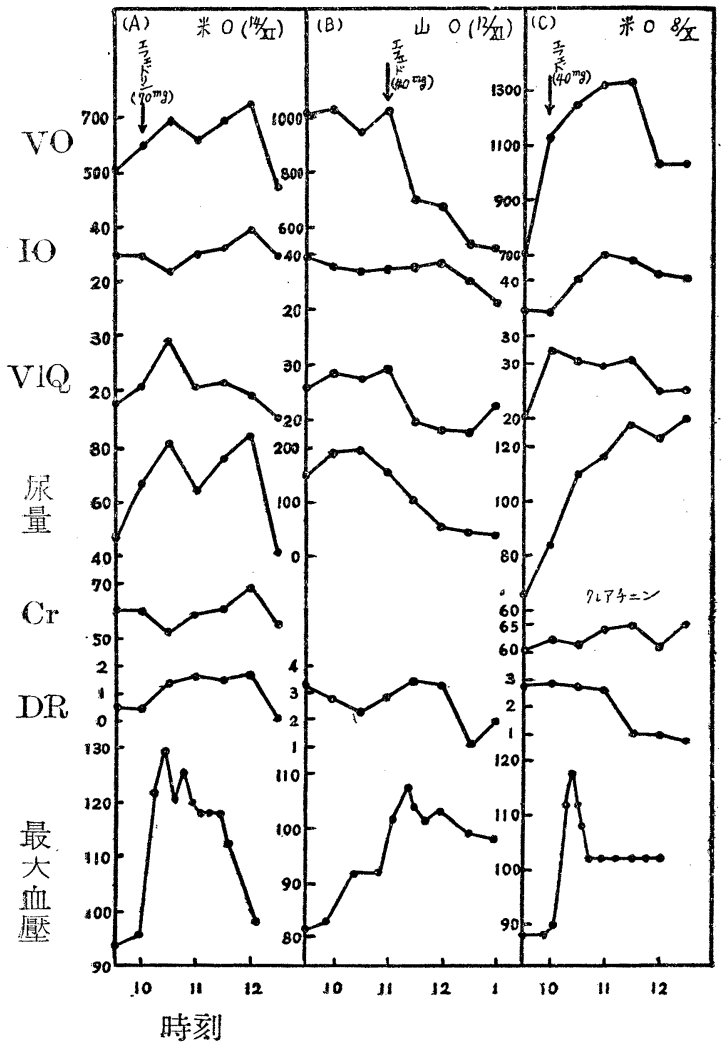

A（エフェドリン $70 \mathrm{mg}$. 筋肉內注射) では注射 後原量はM字型の變動を示し，VOはこれと同 樣の變化な示したが，IOは中や不規則の變動 を示した、VIOは注射後30分で血壓の最高点 に一政して山走示し，その後はむしろ注射前上 り低值示した(アドレナリン注射 $\mathrm{A} の$ 例をほ ぼ同樣)。

B（エフェドリン $10 \mathrm{mg}$. 筋肉內注射）では注 射後尿量の著明の低下が起り, VOも同樣に低 下しだＩO注注射後1時間まではほモんど變化 なく(僅汃に上昇), その後やや急激に低下し, VIQは注射後全体こして低下した。

C（エフェドリン4 $10 \mathrm{mg}$. 筋肉內注射）では注 射後尿量およびVO, IOはいづれも增加し, $\mathrm{V}$ IOは徐々に低下走示した。

以上の成績によればエフェドリンはアドレ ナリン注射の場合と同樣にやはりIOおよびVI Qに對して一定の影響をおよぼさない，血壓の 變化は エフェドリン 注射の埕合にはアドレナ リン注射に比してやや長時間縫續する傾向を示 しだドテヂオ反應に對する影響は明瞭ではな いが.Aにおいては血壓上昇期に一致して僅か ながら上昇を示した。 Maxwell等(9)はエフェド リンの 35〜 75mg. 筋肉內注射は腎機能に特別 の影響なないというがドナデオ反應の變化から みてそのきま舰得することはできない。但しこ の䦓題のくわしい検討性日にゆずる.

\section{實驗6. 寒冷のVIQに及成す影響 (第6圖)}

寒冷刺㦸としては約 $3^{\circ} \mathrm{C}$ 恒溫室にて上半身 裸体になつて30分間曝露する方法を用いた。

この賽験も食事をとらすと行つた。寒冷曝露 により一般に尿量の著明な增加が見られ，Vo をほぼこれと本行して上昇したか，IOはBにお 
第 6 図 寒冷のVIQに及ぼす影響

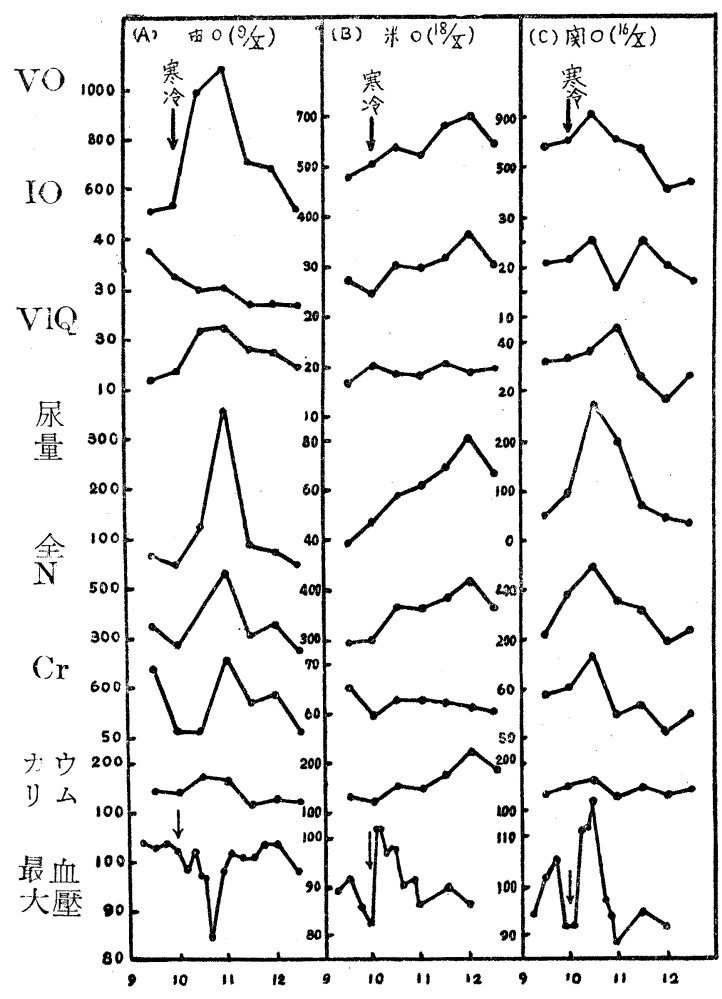

時刻

いてのみほぼVO(從つて沓量) と平行し，A 打 よびCに於ては一定の傾向を示さない、VIQは

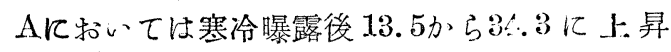
し, 約 2 時間後ほぼ恢復し, Bではほとんご變 化なく，Cで姑32.0から45.9まで上昇し，次で 16.5 まで低下した。血壓は $\mathrm{A} に$ 於ては寒冾曝露 により $102 \mathrm{mmHg}$ 力ら $97 \mathrm{mmHg}$ に低下し, 寒冷 室灾出て更に84まで低下し, 約30分で恢復し た.B怙よびCで寒冷により血壓は上昇した。 然し血壓の變化と尿量その他の變化との間には 一定の關係は認められなん。

クレアチニンは $\mathrm{A}$ 和よびCで恬尿量の增加に 件い增加の傾向を示したが，Bでは著しい變化 は認められなかつた。なおカリウムは VOをや
や似た變動势示したか，これは恐らく尿量こカ リウムとが大体伴つて變動し VOもまた同樣の 傾向走示すことによるもので, 寒冷刺㦸の $\mathrm{K}$ 代 謝に特上ぼす直接の影響ではないと考えられ る・この昜合CIは $\mathrm{B}$ およびCでは瓜量に卅行し て増加したが，Aでは尿量増加期に著變なく， 尿量減少期に著しい減少走示した。

\section{實驗7.手術のVIQに及ぼす影響(第7田)}

手術的侵慜の影響についてはすでに松田(2)の 報告がありこし問題は本論文の主目的ではな いが, 手術に件うドナチオ反隹の變化（宇津野 (10)）とVIOD變化を比較する意味で若干の筫験 在試みた。 $\mathrm{A}(\mathrm{O}$ 崎，46才婦人)は子宮頸胵部癌

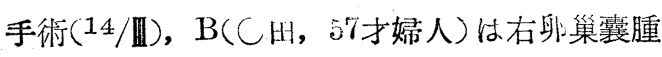
摘出手術 $(23 / X)$ 主行つた。 ○田の採旅は手術 日在2回(午前 8 時10分上り手術直前0)午後L時ま で，午後時より2.日午前恃まで)に分け( 怵 尿した。

手術日あるいは手術後の尿量敊よび尿全Nの 急減飞その後の回復に伴いVOは大体同様の經 過を示したが，IOの變動は一定せす，Aでは 術後ゆるやかな低下を示しBではVOとほぼ乍 行している。全体的にみてIOの術前に對する 術後の低下率はVOのそれより大きいため VIQ は増加する結果こなる.手術後2３日後から蛋 白代謝の昂進(尿全Nの增加)か起るにるかかか らす，IOがAに执いてむしろ術前よりひくい ことは尿量減少から推定される腎藏の排泄機能 の低下によるものか，むるるいはＩOに相當する 不完全酸化物の生成の減少によるものか明かで ない.またBに扣いてIOかVOあるいは尿量と 件つて増加を示すのは, 腎臟機能の昂進による るのか不完全酸化物の生成増加によるのか不朋 
第 7 図手術のVIQK及ぼす影響

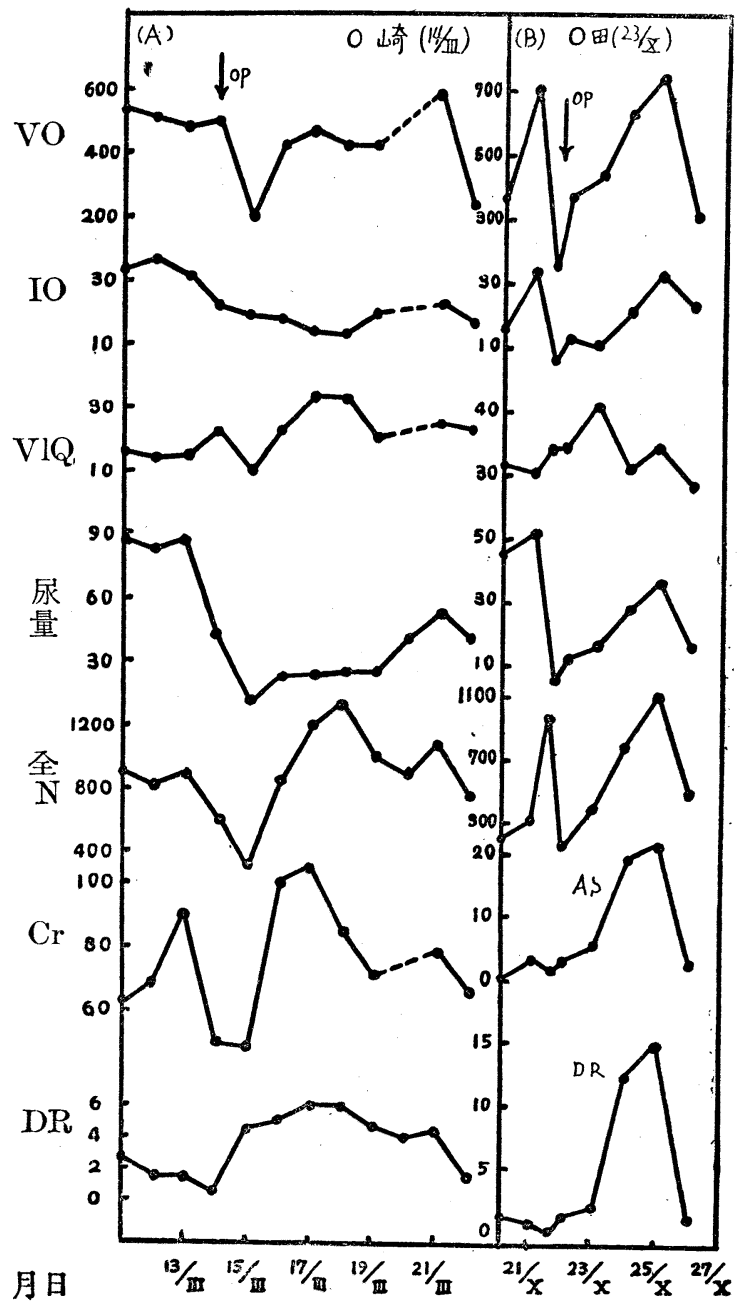

（註） AS：赤矤神明反隹(淸水變法)

である・いずれの場合にも VIQ 估增加を示す から，西風に上れば酸化機能の低下とあらわす こととなるが，簡單にそう結論することは出來 ないように思はれる。

實驗8．尿酸化商（第3図）

VIQこ直接の閣係はないが以上の賽驗にお ける尿酸化商（VO：N)について若干の觀察を 試みた. VOと全Nをは多くの場合平行して 變
動するものであ己から兩者の比をとることは一

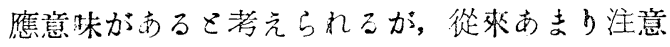
されて抢らなかつた尿量の變化の影響它うけて 平常状態の比較的短時間の觀察においてかなり 著しく變動する．2，3の列灾圖示するこ第8圖 の如くである。

第 8 因尿酸“化啇

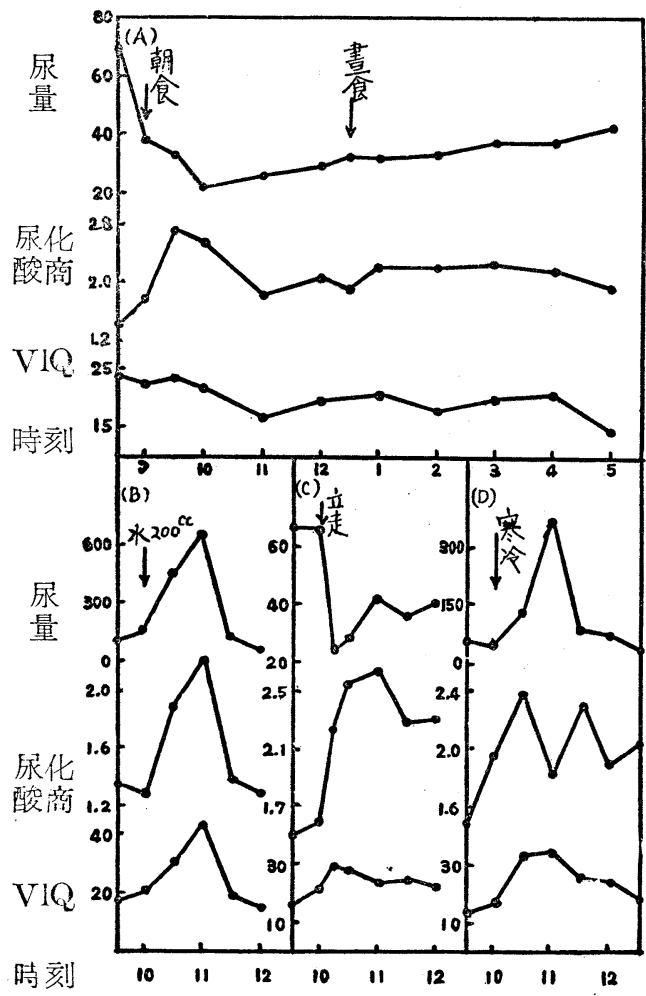

（註）A $\cdots$ 第 1 因Aの賽驗 B……第 2 図 B " C …第 3 因 A " D......第 6 図A

尿Nあるいは蛋白攝取量と尿酸化商つ關係に ついてはすでに齋藤(11)，山地(12)などの研究が ある，尿量の減少により尿Nがへる場合は低蛋 白食の場台と同樣に酸化商壮上昇する傾向を示 し(第3圖 $\mathrm{A}, \mathrm{C}$ )，逆に尿量の增加する場合は酸 


\begin{tabular}{|c|c|c|c|c|c|c|c|c|c|c|}
\hline 條化 & 寊羷例 & & 直前 & 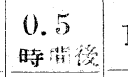 & 1.0時 & 1.5 時 & 2.0時 & 2. 5 時 & & \\
\hline \multirow{6}{*}{$\begin{array}{l}\text { 水 } \\
\text { 分 } \\
\text { 攝 } \\
\text { 取 }\end{array}$} & \multirow{3}{*}{ A } & VO & 100 & 115.9 & 178.6 & 201.3 & 132.2 & 160.7 & & \\
\hline & & IO & 100 & 139.8 & 118.6 & 154.7 & 117.7 & 119.3 & & \\
\hline & & $\overline{\text { VIQ }}$ & 100 & $82,4=$ & 150.7 & 149.3 & 121.6 & 134.5 & & \\
\hline & \multirow{3}{*}{ B } & VO & 100 & 171.1. & 185.4 & 81.7 & 67.6 & & & \\
\hline & & IO & 100 & 117.2 & 87.4 & 87.5 & 90.6 & & & \\
\hline & & VIQ & 100 & 145,5 & 211.5 & 93.2 & 74.6 & & & \\
\hline 條件 & 實驗例 & & 直前 & 0.25 时 & 0.5 時 & 1.0時 & 1.5时 & 2. U時 & 2.5時 & \\
\hline \multirow{3}{*}{ 運 } & \multirow{3}{*}{ A } & $\mathrm{VO}$ & 100 & 66.7 & 76.1 & 79.3 & 80.4 & 80.0 & & \\
\hline & & IO & 100 & 50.0 & 59.4 & 71.9 & 71.9 & 79.9 & & \\
\hline & & VIQ & 100 & 133.6 & 128.6 & 110.1 & 119.8 & 100.0 & & \\
\hline \multirow{3}{*}{$\begin{array}{l}\text { 動 } \\
\text { 至 }\end{array}$} & \multirow{3}{*}{ B } & VO & 100 & 44.7 & 75.6 & 62.7 & 70.2 & 61,9 & -7.1 & \\
\hline & & IO & 100 & 37.9 & 8,4 & 148.9 & 127.9 & 157.4 & 127.4 & \\
\hline & & VIQ & 100 & 117.78 & 894.9? & 42.0 & 54.7 & 39.1 & 44.6 & \\
\hline \multirow{3}{*}{ 走 } & \multirow{3}{*}{ C } & vo & 100 & & 60.8 & 94.9 & 93.2 & 90.0 & & \\
\hline & & IO & 100 & & 42.6 & $1 \div 9.9$ & 100.0 & 135.8 & & \\
\hline & & $\mathrm{VIO}$ & 100 & & 83.7 & 72.9 & 93,2 & 66.4 & & \\
\hline 條件 & 實驗例 & & 直前 & 0.25 时 & 0.5 時 & 1. 0 時 1 & 1.25時 & 1.5時 & 2. 0時 & 2.5 时 \\
\hline \multirow{9}{*}{$\begin{array}{l}P \\
F \\
v \\
\gamma \\
リ\end{array}$} & \multirow{3}{*}{ A } & $\mathrm{VO}$ & 100 & 87.3 & 161.1 & 108.2 & & 78.4 & 61.9 & \\
\hline & & 10 & 100 & 102.4 & 83.5 & 76.7 & & 99.8 & 67.2 & \\
\hline & & VIQ & 100 & 84.9 & 192.8 & 140.9 & & 78.9 & 92.2 & \\
\hline & \multirow{3}{*}{$\mathrm{B}$} & $\mathrm{VO}$ & 100 & 99.1 & 129.5 & 100.8 & 80.1 & 87.1 & 96.7 & 92.0 \\
\hline & & 10 & 100 & 126.4 & 153.2 & 151.8 & 160.4 & 153.6 & 156.0 & 181. 2 \\
\hline & & VIQ & 100 & 78.4 & 84.8 & 66.2 & 55.8 & 56.7 & 61.9 & 50.6 \\
\hline & \multirow{3}{*}{ C } & $\mathrm{VO}$ & 100 & 56.6 & 68.9 & 51.5 & & 56.7 & 57.1 & \\
\hline & & IO & 100 & 69.1 & 69.7 & 80.3 & & 90.1 & 81.6 & \\
\hline & & VIQ & 100 & 81.9 & 98.7 & 64.1 & & 62.8 & 70.0 & \\
\hline
\end{tabular}




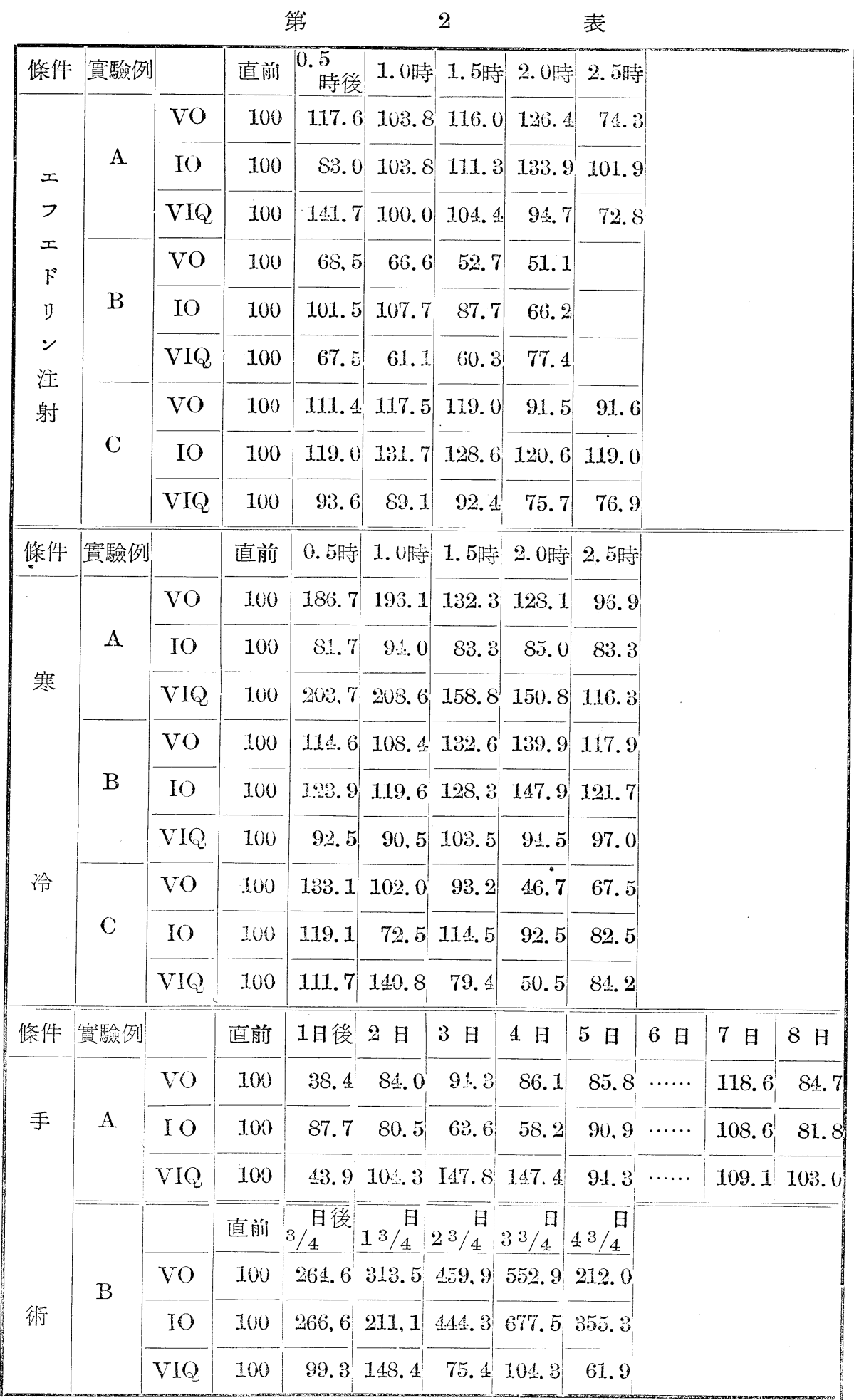




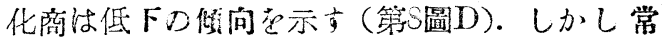
にそうなると良らす，尿量增加に件うNの增 加上りもVOD增加がー層著しいために尿量己 ほぼ本行して酸化商の增加する場合もある (第8圖B). 尿酸化商モVIQ 關係注認められない，恐らく尿酸化商梳嚴密な 意朱では蛋白質の体內酸化状况怘あらわす指標 として信賴しうるものではないように思われ 乃.

\section{洘察}

西風のVIQあるレはMüllerの尿酸化商等に對 して、それらの“係整そのもの”としての意義 存確定的のものこして認める立場からすれば, その係數に留係する兩因子の變動を分㭛的に考 察するここは逆行的な考え方であるかもしれな レ.しかし VIQの上昇分細胞嘰能あるい住生 体酸化㙨能の低下であるという見解の理詥的基 礎は必すしも明瞭ではなく，結局 IOD低下を “疲学性物質のうつ積”そみなすことが主要な基 䂵をなしているにすぎないとすれば，一隹出發 点にかえつてVO拈よびIOの墸種の條件にをも なう變動の状况を詳細に觀察する必要があると 考えられる.

以上にのベた實驗は主として比較的短時間內 の實験であり，西風の䁈驗とは幾分條件を異に していっからこれをもつて西風の所說を否定 することはできない。しかし賽驗した範圍內で はVIQの變動は必すしも全身の細胞機能 ある い估酸化性能つ異常のみにもとづくものとは思 われない，例えば平常の状態においても尿量の

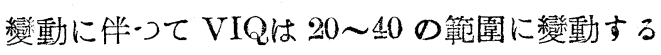
ここがある（第1圖B，第2圖B）. 從つて諸種の 條件にもとすくVIQの變化が尿量の變化の結
果にすぎない場合すあると考えられる。比較的 短時間のはげしい運動の場合（第3圖, Bおよび C) 尿量の減少に伴レVOD減少上りIOの減少 の方が一層强く起る結果VIQの一過性上昇が みられたがその後IOは增加しVIQはむしろ低 下しに.

要するにVIQの算減はVOの變化率（基準の 值に對する\%)民100變化率の相對的笘係によ つて决定されるるので,この垣係とまをめると 第脿打よび第表に示すようになる。

即ち運動その他の條件学負荷する前の值を 100上した時の VOおよび IOD\%の比率かＶIQ の變動に一致することになる。これまでの實験 の範衛內では VOは尿量あるいは尿Nと著しい 相閣学示すが，IOはそれらと一定の關係はな くまた他の如何なる因子とも相關力認められな

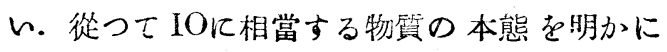
しそれの排浛の變動する生化學的根據が明かと なるまではVOとIOの比を求めることは理椧的 基礁が清弱であるように思われる。しかし實際

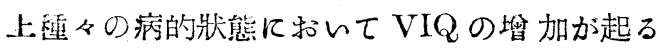
という西風の興来ある研究に對しては以上の貫 験からけ直らに批判することはできない。

綰諭

西風の提唱した痕労测定法こしての 尿Vakat 沃度酸值係數 (Vakr酸素/尿沃度酸值) につ き,その日變動拈よび水分攝取, 運動, アド レナリン注射, エフエドリン注射, 寒冷. 手 術等の影響をVakat酸素括よび沃度酸值の兩因 子の變動との關迋に执いて觀察し次の結論を得 た.

(1). Vakat酸素任單位時間當りの尿量和上 び尿全N量と明かな正相關定示すか;，沃度酸值 
(18)

の變動には全く規則性が認められす。. 從つて Vakat 沃度酸值係數の變動にも規則性が認めら れない。

(2). Vakat沃度酸值係數の上昇が，單なる 尿量の減少あるいは增加にもとずくと思われる 場合があり，Vakat沃度酸值係數の上昇が生体 內酸化㙨能の低下をあらわすという理論的根據 はな敃檢討の餘地があると思わ扎る。

(3). 尿酸化商つ比較的短時間內の變動に對 しては尿量の變動が著明ふ影響をおよぼす場合 がある，從つて㛜密にいえば尿酸化商は蛋白質 の体队酸化状海に對する正確な指整とけなり得 ないと思われる。

終りに臨み御懇包な御指導をいただいた山添 呚授ならびに被検者として赤力された教室員一 同に深く感謝する。

\section{文献}

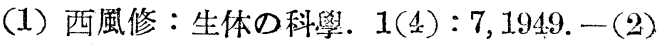
: 松田正二：產婦人科の世界. $2(11): 40,195$ 0. 一(3) 齋藤利信: 生作の科學. $2(3): 1289$ 1950. 一(4) 山添三郎：医學已生物學. 14: (4) : 232, 1949. 一(5) 山添三郎：医學と生物學. 14 （1）：18, 1948．－（6）淸水良雄：医學と生 物學. $15(1): 29,1949 .-(7)$ 齋藤一：学働 科學. $20: 320,1943 .-(8)$ 山添, 由上, 關 本：医學と生物學. $20(4): 166,1951 .-(9)$ Maxwell M. H., Morales P. \& Crowder Ch. H. : Proc. Soc. Exp. Biol. 77(3) : 539, 1951. -(10) 宇津野榮男：医學と生物學. 20(3)： 125, 1951, 一(11) 齋藤一：労働科學. 20 : 261，1943. 一(12) 山地庭本：榮食飞食㷎. 4 4) : 32, 1951. 